\title{
Operationalizing ethics in food choice decisions
}

\author{
Daryl H. Hepting · JoAnn Jaffe · Timothy \\ Maciag
}

Received: date / Accepted: date

\begin{abstract}
There is a large gap between attitude and action when it comes to consumer purchases of ethical food. Amongst the various aspects of this gap, this paper focuses on the difficulty in knowing enough about the various dimensions of food production, distribution and consumption to make an ethical food purchasing decision. There is neither one universal definition of ethical food. We suggest that it is possible to support consumers in operationalizing their own ethics of food with the use of appropriate Information and Communication Technology (ICT). We consider eggs as an example because locally produced options are available to many people on every continent. We consider the dimensions upon which food ethics may be constructed, then discuss the information required to assess it and the tools that can support it. We then present an overview of opportunities for design of a new software tool. Finally, we offer some points for discussion and future work.
\end{abstract}

Keywords food $\cdot$ ethics $\cdot$ ICT $\cdot$ spime $\cdot$ citizen consumer $\cdot$ democracy

\section{Introduction}

There is a large, well-documented gap (Vermeir and Verbeke 2006; Young et al 2010; Carrington et al 2010) between consumers' attitudes and actions when it comes to the purchase of ethical food. This paper focuses on one aspect of this disparity: the difficulty in knowing enough about the various dimensions of food

\author{
Daryl H. Hepting \\ University of Regina \\ Regina, Saskatchewan, S4S 0A2, CANADA \\ Tel.: +1-306-585-5210 \\ Fax: +1-306-585-4745 \\ E-mail: hepting@cs.uregina.ca \\ JoAnn Jaffe \\ E-mail: joann.jaffe@uregina.ca \\ Timothy Maciag \\ E-mail: maciagt@cs.uregina.ca
}


production, distribution, and consumption to be able to make a food purchasing decision that is satisfactorily ethical from the standpoint of the consumer. Given the multiple dimensions and numerous criteria that one might consider, is it possible to support consumers in operationalizing their ethics when buying food? We posit that information and communication technology (ICT) has the potential to provide this support.

Consumers today are faced with a myriad of issues and perceived threats coming from the food system and many arenas for ethics. Food ethics may be related to sustainability, (ag)biodiversity, organics, and locality; to workers, citizenship, farm animal welfare, cultural survival, and health; and for well-being, meaning, autonomy, and justice.

In light of needing to know so much about so many different things in order to take action, it is easy to understand why some might decide to do nothing. In much the same way that BloomBecker (1987) considered computer ethics as an antidote for the despair that people were feeling in the face of uncertainty about the spread of technology, food ethics can also be an antidote for the despair that some consumers report. BloomBecker considered that it may or may not be difficult to determine whether a particular action is ethical, but it may well be more difficult to decide to make that determination. Making sense of all the competing claims about products can be supported by ICT. However, the same technologies that make it possible to "know everything, from anywhere" on the web make it possible for any citizen to remain (blissfully) unaware of the larger context of any particular issue. Information is so individualized to its consumer that the public view becomes obscured. Pariser (2011) coined the term "filter bubble" to describe this phenomenon. It is not surprising that perceived consumer effectiveness, or the feeling that one's actions make a difference, is widely identified (Vermeir and Verbeke 2006) as an effective predictor of action in the context of food systems, which can be diminished if all consumers reside inside their own filter bubbles.

Is it possible to increase consumers' perceived effectiveness to act ethically? This may be tied to improving the robustness of food democracy and participation therein. As participation in electoral democracy depends less on casting a ballot than the ability to engage in the issues and have real meaningful choices, so participation in food democracy depends less on voting with one's purchases than on knowledgeable engagement that provides space for consequential food system alternatives (Johnston et al 2009; Jaffe and Gertler 2006).

In these ways, a choice can be made between thin or weak (food) democracy: providing affluent consumers with guilt-free shopping options that work to reproduce a mode of political participation grounded in individual consumer choice, and strong (food) democracy: new citizen-based modes of engagement that aim for the conscious re-constitution of more equitable, democratic, and sustainable socio-ecological relations in the food system. This dichotomy extends to alternative food networks (Follett 2009) where one can find corporate, weak alternative food networks that focus on protecting the environment; and local, strong alternative food networks that (may) focus on protecting the environment as well as labour standards, animal welfare, rural communities, small-scale farmers, and human health.

In this work, we consider the opportunity for consumers to use ICT in order to articulate and operationalize their food ethics when choosing foods. We further elucidate ways in which particular forms of ICT can be used to build transforma- 
tive practices as citizen-consumers move towards food democracy. As such, this work contributes to the discourse about food ethics and may be of interest to academicians and activists who work in this area. We consider eggs as an example because locally produced options are available to many people on every continent (Alders and Pym 2009). We consider first the dimensions upon which food ethics may be constructed, and then discuss the information required to assess it and the design considerations for tools that can support it. We then present an overview of opportunities for a new software tool, that we propose, to be used by consumers, casual and otherwise, to support them in their purchase decisions. Finally, we offer some points for discussion and future work.

\section{Food Ethics}

Related to the growth of political concerns about food, the rise of food ethics since the 1980's is recognition that there are several possible futures for the food system and much is at stake. Before this time, food was widely considered to be ideologically and politically neutral; food system issues were understood to be scientific-technical questions of guaranteeing food safety, food production and "choice" (construed as the number and range of items), and availability of and access to food, with governments, agribusiness, and consumer groups, respectively, strictly dividing responsibility for these outcomes (Korthals 2006). Consumers themselves were widely seen as needing little information beyond knowing to buy what agribusiness was selling (Jaffe and Gertler 2006). While the conventional system remains concerned with these essentially quantitative questions - and indeed, seeks to contain struggles around food to this terrain - activists have moved to enlarge the field into the qualitative. Even within these bounds, activists have endeavoured to demonstrate the values and ethical content of what appear to be scientific issues, for example, by pointing out the implications of limiting definitions of food safety to short-term issues such as contamination and spoilage and omitting long-term or broader issues of health and ag-biodiversity.

A quick entry into the discussion is by way of $\mathrm{SOLE}^{1}$ (Sustainable Organic Local Ethical) food. Thinking about food in terms of SOLE may be seen to be seeking reconnection between people and the food they eat, the places where that food is grown, and by whom it is raised. What might be SOLE food for one person, however, may not be for another. The most obvious difficulty centers on locality: certain foods may be produced sustainably, organically, and ethically in one place but not another - which would indicate the potential need for different diets in those different locations. Local can be viewed at different scales under different circumstances, and what is seen as local at any particular moment may depend on geography, history, climate, and so on, as well as in relation to what it is being judged. Further, the reason people value "local" may be different. Some may see it as inherently more sustainable, while others are "defensive localists", protecting their home regions (Winter 2003).

Considerably more problematic is ethics. While one may desire to consume food that is ethically produced, people have different ethical values, standpoints, and

\footnotetext{
1 coined by Bonnie Azab Powell in 2006, as a possible name for the blog she was starting, which became known as the Ethicurean (http://www.ethicurean.com), with the tag line "Chew the right thing".
} 
concerns. Should one's ethics focus on animal welfare, worker welfare, environmental welfare, or all of the above? Moreover, sustainability, organic agriculture, and local production all entail ethics in their own right. Certainly, there is an ethics of economic sustainability: for instance, people have a right to food (Mechlem 2004) and the economically disadvantaged may not have practical access to the full array of choices afforded to more affluent consumers. Further, some may view the terms of SOLE as necessarily needing to be considered together, so that SOLE food is synonymous with food democracy, which strives to meet democratic needs in the organization and scale of food systems that are sensitive to resource utilization and depletion and which provide opportunities for citizens to obtain greater control and engage in more meaningful interactions with producers (Johnston et al 2009). For others, these terms may diverge radically.

While the idea of SOLE food opens a door onto the discussion of ethics in the food system, it also points to the considerable difficulty in arriving at a onesize-fits-all solution to ethical consumption. In addition to the differing values and standpoints of consumers is the issue of a lack of transparency in food systems, which hides not only the details of production, but the relationships embodied in food commodities, known as commodity fetishism (Hudson and Hudson 2003; Marx 1992/1867). Transparency alone, however, is insufficient to enable informed scrutiny of power in the public sphere. When presenting information for action, it must be accompanied by assessment ("how accurate, reliable and significant information is to the situation at hand") (Marsh 2011), salience ("how relevant information is to those making decisions or choices") (Marsh 2011; Cash et al 2002), credibility ("how authoritative, believable, and trusted information is perceived to be"), and legitimacy ("how 'fair' an information-producing process is believed to be") (Cash et al 2002).

In our view, these difficulties and differences are important because we see ethics as going beyond satisfying one's individual needs in the marketplace. We would argue, rather, that ICT may provide a public arena for new political action around food. To do so, we propose to take account of ethical differences and construct them into group actions. In other words, we propose a two-way flow of knowledge, with the return flow consisting of the structured concerns of citizenconsumers.

We propose to use a table based on Mepham's (2000) ethical matrix as a guide to ethical deliberation about food. It frames the deliberation in terms of impacts of principles (well-being, autonomy, justice) on stakeholder groups (people in the food industry, citizens, farm animals, and the living environment). We then locate various forms of ethical guidance, discussed below, in relation to this matrix (Table 1). This table integrates Mepham's concerns with Zwart's (2000) 3 historical themes (health \& welfare, freedom \& choice, and fairness), Singer and Mason's (2006) 5 foundational ethical principles for "Making Conscientious Food Choices", and Lusk and Briggeman's (2009) 11 values that people associate with food.

From Singer and Mason(2006): Transparency (1), which may be better described as pro-ethical (Turilli and Floridi 2009) in that it facilitates ethical behaviour in relation to food, must be accompanied by salience, credibility, and legitimacy. Fairness (2) is achieved if producing a food does not impose costs on others, broadly construed. Humanity (3) is reflected in care for animals. Social Responsibility (4) refers to work conditions and pay. Needs (5) grants primacy 
Table 1 Mepham's ethical matrix with other ethical guidance added from Zwart (2000), Singer and Mason (2006), and Lusk and Briggeman (2009).

\begin{tabular}{|c|c|c|c|}
\hline Respect for & $\begin{array}{l}\text { Well-Being } \\
\text { (Health \& Welfare) }\end{array}$ & $\begin{array}{l}\text { Autonomy } \\
\text { (Freedom \& Choice) }\end{array}$ & $\begin{array}{l}\text { Justice } \\
\text { (Fairness) }\end{array}$ \\
\hline \multirow[t]{2}{*}{$\begin{array}{l}\text { People in the } \\
\text { Food Industry }\end{array}$} & $\begin{array}{l}\text { Income } \& \text { working } \\
\text { conditions }\end{array}$ & Freedom of action & $\begin{array}{l}\text { Fair trade laws } \& 3 \\
\text { practices }\end{array}$ \\
\hline & $\begin{array}{l}\text { Social Dimension, } \\
\text { Social Responsibility }\end{array}$ & $\begin{array}{l}\text { Social Dimension, } \\
\text { Social Responsibility }\end{array}$ & $\begin{array}{l}\text { Social Dimension, } \\
\text { Social Responsibility, } \\
\text { Fairness }\end{array}$ \\
\hline \multirow[b]{2}{*}{ Citizens } & $\begin{array}{l}\text { Food safety }{ }^{\mathcal{S}} \\
\text { quality of life }\end{array}$ & $\begin{array}{l}\text { Democratic, } \\
\text { informed choice }\end{array}$ & $\begin{array}{l}\text { Availability of } \\
\text { affordable food }\end{array}$ \\
\hline & $\begin{array}{l}\text { Social Dimension, } \\
\text { Contamination, } \\
\text { Dietetics, } \\
\text { Naturalness, } \\
\text { Nutrition, } \\
\text { Origin, } \\
\text { Appearance, } \\
\text { Convenience, } \\
\text { Safety, } \\
\text { Taste, } \\
\text { Tradition } \\
\end{array}$ & $\begin{array}{l}\text { Social Dimension, } \\
\text { Contamination, } \\
\text { Dietetics, } \\
\text { Naturalness, } \\
\text { Nutrition, } \\
\text { Origin, } \\
\text { Transparency }\end{array}$ & $\begin{array}{l}\text { Social Dimension, } \\
\text { Fairness, } \\
\text { Needs, } \\
\text { Price }\end{array}$ \\
\hline \multirow[b]{2}{*}{ Farm Animals } & Animal welfare & Behavioural freedom & Intrinsic value \\
\hline & $\begin{array}{l}\text { Social Dimension, } \\
\text { Humanity }\end{array}$ & $\begin{array}{l}\text { Social Dimension, } \\
\text { Humanity }\end{array}$ & $\begin{array}{l}\text { Social Dimension, } \\
\text { Humanity, } \\
\text { Fairness }\end{array}$ \\
\hline \multirow[b]{2}{*}{$\begin{array}{l}\text { The Living } \\
\text { Environment }\end{array}$} & Conservation & $\begin{array}{l}\text { Maintenance of } \\
\text { biodiversity }\end{array}$ & Sustainability \\
\hline & $\begin{array}{l}\text { Social Dimension, } \\
\text { Environmental } \\
\text { Impact }\end{array}$ & $\begin{array}{l}\text { Social Dimension, } \\
\text { Environmental } \\
\text { Impact }\end{array}$ & $\begin{array}{l}\text { Social Dimension, } \\
\text { Environmental } \\
\text { Impact, } \\
\text { Fairness }\end{array}$ \\
\hline
\end{tabular}

to eating for survival, but fulfillment of that need should be done as ethically as possible, based on the other principles.

From Lusk and Briggeman (2009): Naturalness (1) is the extent to which food is produced without modern technologies; Taste (2) is the extent to which consumption of the food is appealing to the senses; Price (3) is the price that is paid for the food; Safety (4) is the extent to which consumption of food will not cause illness; Convenience (5) is the ease with which food is cooked and/or consumed; Nutrition (6) is the amount and type of fat, protein, vitamins, and other nutrients; Tradition (7) encourages preservation of socially and culturally meaningful consumption patterns; Origin (8) is concerned with where the agricultural commodities were grown; Fairness (9) is the extent to which all parties involved in the production of the food benefit equally; Appearance (10) is the extent to which food looks appealing; and Environmental Impact (11) is the effect of food production on the environment. Note that many of these concerns themselves are complex and contested, and would be difficult to simply specify. Further, it would virtually impossible to satisfy all ethical principles and values simultaneously.

From Table 1, it is apparent that most of the ethical considerations relate to our own well-being. A focus on the social dimension of food gives us the broadest coverage, which implies some capacity to defetishize food commodities (Johnston et al 2009). 


\section{Food Information}

The historical process of deskilling coupled with the increasing distance between producer and consumer means that most of the information with which a consumer must make a decision comes through labelling, some form of certification, or alternative channels outside the regulatory framework. Today's consumers have lost touch with those who produce the food they eat, and so they must rely on various intermediaries.

The successful workings of the food system rely upon enforceable trust. Whereas government food inspection agencies once provided assurance to consumers, recent food safety scares have highlighted problems with that oversight. If these information sources are to be trusted (Brom 2000; Nilsson et al 2004), there is a risk of applying a non-compensatory decision process that takes only nutritional characteristics or credentials into account when making decisions. In other words, in the absence of a knowledgeable 'consumerate', there is a danger of flattening quality considerations into a few objective elements that can be regulated or certified (Jaffe 2009), which will be intensified as threats to the system intensify. This also represents a kind of commodity fetishism, because the details of the whole food, or the precise requirements of the certifications may remain unexamined. Whitmore et al. (2010) describe the alternatives as Full Information Product Pricing (FIPP) networks, which may have several idealized types. The different types are illustrated with an example involving eggs.

The citizen-consumer may begin with the perspective that "an egg is an egg" and that there are no meaningful distinctions to be made between different egg suppliers. She may become aware of battery cage egg production and decide to do more research. She learns about the 5 freedoms for animal welfare (Webster 2001): freedom from thirst, hunger and malnutrition - by ready access to fresh water and a diet to maintain full health and vigour; freedom from discomfort by providing a suitable environment including shelter and a comfortable resting area; freedom from pain, injury and disease - by prevention or rapid diagnosis and treatment; freedom to express normal behaviour - by providing sufficient space, proper facilities and company of the animal's own kind; and freedom from fear and distress - by ensuring conditions which avoid mental suffering. She decides only to buy eggs from producers who grant these freedoms to their laying hens. Yet, how is she to choose?

\subsection{Face-to-Face Producer-to-Consumer Networks}

The most direct way to regain food knowledge is to seek out local producers and become knowledgeable about their practices. A citizen-consumer may choose to contact local egg producers and ask them if they uphold the 5 freedoms. To verify producers' answers, she may visit those who have said "yes". Such a commitment is quite onerous, yet rewarding. She will gain knowledge about the food she eats, create valuable linkages with local producers, and make a positive contribution to food democracy in her locality. This is the "gold standard" for Full Information Product Pricing (FIPP) networks (Whitmore et al 2010) and it is well-suited to small-scale operations. As farmers attempt to scale up their production, direct contact with citizen-consumers becomes more difficult. 


\subsection{Consumer-Driven Social Computing System}

If a citizen-consumer does not know whom to contact, or, if there are other things to ask about egg production, she may first look towards a Consumer-Driven Social Computing System.

Knowmore (http://knowmore.org/) was a community portal promoting ethical consumerism, first online in 2005 and its last snapshot in the internet archive (http://archive.org/web/web.php) is from June, 2013. The knowmore system employed a type of moderated crowdsourcing: any knowmore member could contribute information towards the development of "responsibility profiles" for organizations and corporations that were finalized by system moderators. Each profile was based on performance in 5 areas: Workers rights; Human rights; Environmental; Political Influence; and Business Ethics. Knowmore ${ }^{2}$ had 7 pages that mentioned promises from retailers to buy cage-free eggs.

Buy It Like You Mean It (http://www.bilumi.org) came online in 2007, employing a form of crowdsourcing. Its last snapshot in the internet archive is from November, 2011. Similar to knowmore, the primary objective was to provide citizens with the ability to access, and contribute to, a repository of items annotated with ethical, social, and environmental qualities. The bilumi system emphasized the notion that consumers can exercise control, through their spending decisions, over which products are made available for purchase. Citizen-consumers were encouraged to contribute to the database by entering information about a company's business practices and ranking the company's behaviour on a 9-point scale from "Amazing" to "Dreadful". Companies could also be scored on specific attributes, including: animal rights, company ethos, reducing and recycling waste, reducing toxic and hazardous materials, quality control, safe working conditions, food handling safety, conserving energy, fair working conditions, and transparency. Bilumi ${ }^{3}$ had 2 notes about the US Certified Organic label.

Such systems have lower direct cost, but it may be difficult to maintain contributions and momentum. Indeed, although both the knowmore.org and bilumi.org websites were still live in April, 2011, their content no longer appeared to be updated.

Sourcemap (http://www.sourcemap.com) is another example of a decision support tool enabling ethical, socially responsible, and environmentally friendly consumerism. Sourcemap ${ }^{4}$ is a crowdsourced consumer portal that enables citizenconsumers to visualize how items/products are made. Sourcemap can provide citizen-consumers with detailed interactive maps that illustrate from where products are sourced.

Hepting et al (2007) describe various attempts to use different communication channels to facilitate reconnections between citizen-consumers and producers. The most successful of these has been a google map (http://bit.ly/lofosask), created in 2008 and maintained by a small group of contributors. It has received over 73,000 views $^{5}$. It provides a list of producers and their products, along with local food retailers and restaurants. It does not provide a search capability beyond

\footnotetext{
2 Accessed April, 2011

3 Accessed April, 2011

4 Accessed September, 2013

5 Accessed September, 2013
} 
the basic. Development of a stable online community is difficult. Using several channels of computer-mediated communication is time-consuming and perhaps counter-productive. The tyranny of choice on the internet presents the hazard of diluting one's efforts.

Systems of this type can help citizen-consumers to make sense of the nuances of different certification schemes. Not all of the schemes may do what citizen-consumers think they do. The Cornucopia Institute's organic egg scorecard $^{6}$ (http://www.cornucopia.org/organic-egg-scorecard/) is a good example of a resource that enables the use of criteria important to organic production in wholesale and retail purchase decisions. The scorecard allows citizen-consumers to distinguish between eggs coming from ethical family farmers and those deriving from industrial producers.

Table 2 summarizes the criteria used in assigning scores. Surprisingly, the organic certifying agent also figures in the score.

\subsection{Voluntary Certification Organizations}

If a citizen-consumer decided that there was too much to learn about egg production, she may choose to look for a certification of some kind, without investigating the requirements of each. A voluntary, or private, certification may be attractive target for citizen-consumers because she may choose one that is tailored to heer interests. Freedom Food ${ }^{7}$ (http://www.freedomfood.co.uk) is the RSPCA's farm assurance and food labelling scheme, which is focused solely on improving the welfare of farm animals raised for food. In the United States, http://www.certifiedhumane.org $/{ }^{8}$ is a similar certification body. More and more retailers are looking to third party certifications to differentiate their offerings to consumers.

\subsection{Government-Sanctioned Certification Regimes}

If a citizen-consumer chooses a certified-organic egg producer, they may have greater trust in the process. However, this standard does not have the ability to differentiate producers: there is one standard and it is not possible to identify which producers exceed its requirements (in terms of animal welfare, access to pasture, and so on).

Where standards and certifications differ, it is important to be knowledgeable about the standards in order to understand in which areas the differences are salient. Although cruelty-free and organic would seem to be synonymous, there may be important differences.

\footnotetext{
6 Accessed July, 2013

7 Acccessed September, 2013

8 Accessed September, 2013
} 
Table 2 Organic Egg Scorecard criteria. All contribute equally to the total score. Detailed information about the criteria can be found at: http://www.cornucopia.org/organicegg-scorecard/Scorecard_Appendix.pdf.

\begin{tabular}{|c|c|c|}
\hline & Criterion & Most Highly Rewarded \\
\hline & Ownership Structure & $\begin{array}{l}\text { "Family Farm (owned and operated by resident } \\
\text { farm family)" }\end{array}$ \\
\hline 2. & Organic Certifying Agent & $\begin{array}{l}\text { "Certifying agencies that have not, to our knowl- } \\
\text { edge, approved henhouses without adequate out- } \\
\text { door space" }\end{array}$ \\
\hline 3. & Egg Supply & "All eggs produced on single-family farm" \\
\hline 4. & Disclosure & "Full and open disclosure" \\
\hline 5. & Commitment to Organics & $\begin{array}{l}\text { "Exclusively organichenhouses and other crops, } \\
\text { commodities and livestock" }\end{array}$ \\
\hline 6. & Single or Double Henhouses & "Single" \\
\hline 7. & Outdoor Space & "5 or more square feet per bird" \\
\hline 8. & Popholes/Exit to the Outdoors & $\begin{array}{l}\text { "Birds kept on rotated pasture in mobile housing; } \\
\text { or at least } 1 \text { large door for fewer than } 500 \text { birds" }\end{array}$ \\
\hline 9. & Outdoor Space Exemptions & "Outdoor access year-round" \\
\hline 10. & $\begin{array}{l}\text { Outdoor Opportunity for all } \\
\text { Birds to be Outside Simultane- } \\
\text { ously }\end{array}$ & "Yes; $100 \% "$ \\
\hline 11. & Rotation of Outdoor Space & "Rotated pasture; mobile housing" \\
\hline 12. & Outdoor Vegetation & "Rotated pasture with mobile housing" \\
\hline 13. & Indoor Space per Bird & "¿ 1.8 square feet per bird" \\
\hline 14. & Indoor Enrichment & $\begin{array}{l}\text { "perches, scratching areas and deep litter; produc- } \\
\text { ers granting year-round outdoor access on pasture } \\
\text { also receive the highest score for indoor enrich- } \\
\text { ment" }\end{array}$ \\
\hline 15. & Natural Light & $\begin{array}{l}\text { "Birds have ample access to the outdoors for nat- } \\
\text { ural light" }\end{array}$ \\
\hline 16. & Other Animals on Pasture & $\begin{array}{l}\text { "pasture rotated and shared with other livestock, } \\
\text { such as cows, goats, sheep" }\end{array}$ \\
\hline 17. & Cycling of Nutrients - Manure & $\begin{array}{l}\text { "Manure is recycled on the farmused as fertilizer } \\
\text { for crops and/or pasture" }\end{array}$ \\
\hline 18. & Feed Produced on Farm & "All feed is produced on farm" \\
\hline 19. & Replacement Stock & "Farm raises own pullets from chicks" \\
\hline 20. & Laying Hen Lifespan & "Hens live out natural lifespandie a natural death \\
\hline 21. & Beak Trimming & "No beak trimming" \\
\hline 22. & Farm Support & "Farmer-owners live/work on-site" \\
\hline
\end{tabular}

\subsection{Proprietary Supply Chain Driven System}

The consumer may also choose a Proprietary Supply Chain Driven System, which generally features less transparency for the consumer, if that consumer is willing to trust the retailer or the information provider.

GoodGuide fits best here because it does not crowdsource its information, and does much of its own research on product supply chains. Sourcemap may also be considered as an example here, when it is used to visualize corporate (not crowdsourced) data.

GoodGuide $^{9}$ (http://www.goodguide.com/) enables ethical, socially responsible, and environmentally sustainable consumerism by allowing its users to access expert-based ratings for a wide variety of products, including food. Each item in

\footnotetext{
9 Accessed September, 2013
} 
the database comes with a single score between 0 and 10, derived from the combination of separate scores for Health, Environment, and Society, each of which comprise many factors. The GoodGuide condenses a complex evaluation of many alternatives into a single, actionable, number. If a citizen-consumer agrees with the way that GoodGuide does its computations, a great deal of research and evaluation time can be saved. However, GoodGuide thereby diminishes her capacity to defetishize. Although GoodGuide values transparency, when examining a score for a particular product, it may not be immediately clear how that score was computed. GoodGuide does not invite direct participation from its users when developing content. GoodGuide lists 1 certified organic brand of egg whites. There is no information about the source of the eggs.

One last important case to consider is when none of the local egg suppliers grant the 5 freedoms of animal welfare to their laying hens. In none of these idealized FIPP networks is it possible to assess demand for the cruelty-free eggs for which our citizen-consumer is searching. This is a serious issue if we seek to move the food system into more humane and ethical directions.

In each case above, the citizen-consumer is at the mercy of product labels or external information. With the information she gains, they are able to exercise limited consumer autonomy.

\section{Opportunities for New Citizen-Based Modes of Engagement}

While existing systems provide support for many things that citizen-consumers would like to do, there remain some unfulfilled needs. There are problems with these other systems: local variations of knowledge are difficult to represent and the historical context may be difficult to locate; it may be difficult to convert knowledge into action with respect to ethics, especially at the personal level; and there is no recourse to demand better products.

Therefore, we propose 3 innovations that address these deficiencies.

\subsection{Spatial and Temporal Information}

For citizen-consumers who wish to inform themselves about the food they eat and the salient questions to ask about it, it may be possible to locate information on the internet which is generic, lacking in the spatial and temporal context. Both these components are important. Locales may have different regulations, different constraints, and so on. Historical information is also important to learn about different models of production or management that were successfully applied before, and also to provide context for the interpretation of generic information. Here, eggs provide an excellent example. The recommendations about cholesterol have changed over the years (Sparks 2006). Now that eggs are becoming a functional food (Surai and Sparks 2001), there may be new ethical implications.

To address these spatial and temporal deficits, we consider an implementation of spimes (Sterling 2005; Maciag and Hepting 2010). Spime is a neologism derived from the words space and time. A spime exists in space and time, in relation to an object's past, present, and future. A spime is an object whose "informational support is so overwhelmingly extensive and rich that it is regarded as a material 


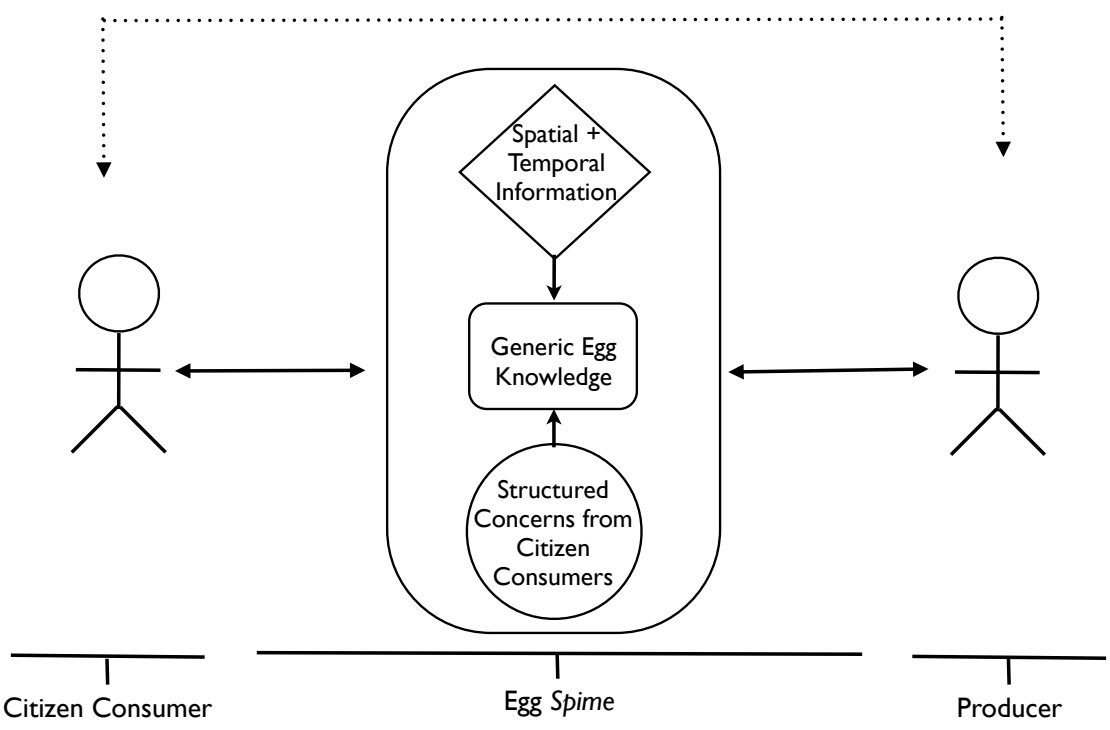

Fig. 1 The egg spime comprises generic egg knowledge, spatial and temporal information about the eggs available at a specific time and place - situated within the local historical context, and structured concerns from other citizen-consumers - eggs to avoid or to choose. A citizen-consumer, with particular ethical concerns, queries the spime and receives information about which eggs are suitable selections. If no suitable alternatives are available, she may choose to communicate her requests for higher quality products. A producer provides information about her eggs and receives requests for higher quality products. The spime mediates and facilitates communication between citizen-consumers and producers.

instantiation of an immaterial system" (Sterling 2005). It is the tip of an iceberg that does not exist on its own: the wealth of information it represents is collected and shared by a community of concerned citizen-consumers. Spimes support lifecycle analysis of products because all of the related information is linked. They are uniquely identifiable, to a fine-grained level, and can be traced through space and time. They support cradle-to-cradle methods, having informational qualities that describe recapturing, recycling, and re-manufacturing of objects (McDonough and Braungart 2002). Spimes, as an informational product, give a citizen-consumer the potential to partially defetishize commodities by allowing her to see the food not only in terms of the final product that is consumed, but in terms of the relationships all along its life cycle. Spimes also promote a community view of information where generic resources can be augmented with local information and remixed.

Consider a dozen eggs bought from a local farm, which were packed on a certain date. Aside from knowing when and from where the eggs came, a great deal more general and specific information is possible. Different consumers may have different levels of knowledge, have different mental models, and so want to know different 
things. What are the breeds of the egg layers? What are the management practices on the farm? How can one judge the freshness of an egg? What are the parts of an egg? What were the layers fed? What is the nutritional composition of an egg, in general, and from this farm specifically? What certifications does this farm have? How were the eggs transported from the farm? The answers to these questions are available to be codified and made accessible on the internet, as shown in Figure 1.

This information supports recent concerns about food traceability (Regattieri et al 2007). Whereas technical solutions may be legislated for large producers, small producers could benefit from solutions which do not require a large capital investment and that leverage data collection activities which are done for other purposes. For example, simply by recording the number of eggs collected each day the farmer could allow a citizen-consumer to see seasonal and annual variations in production for the farm, which could be compared to typical averages under different modes of production. Citizen-consumers can learn about egg production in general and about eggs produced on a certain date at a certain farm. With this information, it is possible to learn about best practices for a particular area and get sufficient information to allow the triple top line (McDonough and Braungart 2002) approach to be used.

\subsection{Operational Ethics}

In the era of post-normal science, new methods are needed for dealing with problems requiring decisions (Munda 2004). Social Multi-Criteria Evaluation (SMCE) provides a possible framework. Faced with the complexities of modern food choices, it is possible to reduce the complexity of the decision by considering only one of multiple dimensions or to face the inherent real-world complexity. There is also at least a third option: to abandon any thoughtful consideration of the complexities and rely on external signals, such as price. Empowering citizen-consumers to shop according to their ethical stance allows them to develop a moral self, to live a morally examined life and to hold positions in political conflicts (Zwart 2000); to develop for themselves an antidote for despair (J. J. BloomBecker. 1987).

As Mepham (2000) advises, the ethical matrix is not a decision model yet it does facilitate scoring of alternatives in relation to one another. In a similar fashion, we propose a co- operatively-generated report card based on the union of all salient concerns with respect to a particular food. For eggs, the organic egg scorecard could be used as a basis. With this information, a ranked list of eggs (from different sources) according to an individual citizen-consumer's perspective could be provided. Mindful of the pitfalls of isolation and filter bubbles, the rankings could also reflect issues identified by the larger community - so that citizen-consumers are engaged in the larger debate.

\subsection{Specification}

If there are no acceptable egg alternatives for citizen-consumers, they may choose to select an inferior alternative. However, to improve the clarity of the demand signal, we propose a means for citizen-consumers to specify the demand for highquality eggs. This facility is a means to operationalize the concept of the triple top 
line (McDonough and Braungart 2002), by working to advocate for higher quality food production systems for eggs.

Buyer-driven systems, made famous by http://www.priceline.com/ ${ }^{10}$, which employ conditional purchase orders (Kelsey and Schneier 1997) can be used to good effect. Furthermore, for many years the food retail industry has embraced ECR (Efficient Consumer Response) (Corsten and Kumar 2005) and CPFR (Collaborative Planning, Forecasting and Replenishment) (Barratt 2004) to improve their profitability and performance. Similar tools, provided to producers and consumers, can also have a positive effect. In a sense, we look to democratize and adapt these technologies for use by people instead of companies.

Whatever consumer autonomy is possible can be channeled here to enable positive signals to be sent to producers and the food production system that allow ethical and moral ideals to elevate the discourse about food production. There is an opportunity for information and communication technology to help in comprehending the size of current and potential demand for food and to amplify the message for regulatory reform.

\subsection{ICT in a Transformative Ethical Practice}

We see our proposal to operationalize ethics as a potential contribution to a transformative food politics (Levkoe 2011). In our analysis, how individuals consume or provision their families through the food system is less a matter of personal choice or attitude than it is a question of practice, convention and identity. In this way, the issue of lack of food literacy is about the widening gap between what consumers can know about and control in the food system as opposed to leading actors in the food chain, as well as how corporations create appropriate consumers for the products they produce (Jaffe and Gertler 2006). Further, people's consumption is organized around an engagement with the "ordinary" ways of doing things according to what is appropriate to a particular situation, which itself is affected by their social location and identity (Evans 2011; Jaffe 2008). What we advocate, therefore, is a mechanism through which the food literacy gap can begin to close through both the provision of ethically-relevant and reliable information and a method whereby unmet demand for ethical processes and products can be conveyed. One can point to a corporate response to emerging ethical and sustainability conventions, practices and identities. The fast-food company, Chipotle, for example, uses free-range, hormone-free meat and dairy, and local produce, "when practical", and finds this a profitable market niche. (Chipotle has also signed, under pressure, the Immokolee Workers' Fair Food Agreement, which aims to guarantee Florida farmworkers fair compensation and working conditions (http://ciw-online.org/ $)^{11}$.) Chipotle, with its "Food with Integrity" motto, has based its success on being able to reach middle-income consumers with the message that food production should be healthier and more ethical. While this partial or incremental acknowledgement of food ethics is encouraging, citizen-consumers should not have to rely on the goodwill and ability of ethical considerations to survive in a competitive market. Rather, a transformative food politics depends upon

10 Accessed September, 2013

11 Accessed September, 2013 
all citizen-consumers having "equal and effective opportunities for participation in shaping that system, as well as knowledge about the relevant alternative ways of designing and operating the system" (Hassanein 2003). In the face of barriers that include government and institutional policy, this proposed operationalization of food ethics via ICT would support citizen-consumers in realization of their rights and responsibilities (Wilkins 2005). Further, we would argue that information and communication technologies offer the possibility of going beyond the limits of individual action. They can contribute to the formation of new groups and identities, as well as a new normal, as their potential collective nature allows for the creation of alternative practices as well as the emergence of a counter-hegemony to the prevailing narrow concerns of price and convenience.

As we have seen with the rise of consumer protection laws and environmental impact assessment in the 1970s and 1980s in North America, social movements can influence the prevailing practices of corporations and governments and the hegemonic ideology of a particular time and place. The food movement, itself, has already had an impact, but one that has often been co-opted and conventionalized. Although its most important effect has arguably been in the area of government regulations - particularly in the areas of phyto-sanitation and food safety - one might claim that these amount to a band-aid that hides the nature of the food system as it is, but does not redesign or remake it from the ground up - a renewal which is necessary if we are to move towards real sustainability or a robust food ethics. In fact, these regulations may mask tremendous social and ecological costs in the medium- and long-term and may allow a large-scale, corporate-industrial system to persist that might otherwise be more fundamentally challenged or begin to fall from its own weight. Further, these regulations may ironically impede or eliminate the ability of more inherently sustainable and ethical producers to participate in the food system due to increased costs of various types, lack of institutional supports, infrastructure, and networks, and barriers to entry (c.f. Worosz et al 2008). These unintended consequences might be mitigated or avoided with better and more complete knowledge and the organizational and institutional flexibility to act on it. Structured concerns from citizen-consumers, together with knowledge about the food system and the means to deploy it, could allow for the ability to operationalize ethics in nuanced ways and to send meaningful information to producers and other actors in the food system to realize more desired ends. While the ICT support tool could be maintained amongst the citizenry on its own as a form of peer production (such as is the case with Wikipedia) (Benckler and Nissenbaum 2006), with pressure, it could be adopted by government and organized as a form of co-production (Linders 2012). Further elaboration of co-production and democratization of the food system could then be pursued in which citizen-consumers using this tool would have the resources available to make food policy, devise plans, and monitor the effects of rules and regulations. Citizen-consumers would be able to gain "an outcome, share more responsibility, and manage more risk in return for much greater control over resources and decisions" (Horne and Shirley 2009, quoted in Linders 2012). ICT could further facilitate this co-production by helping government to co-ordinate citizen action and citizen-consumers to organize themselves. 


\section{Conclusion}

Considering different models for disseminating product information, we found some crucial gaps in their capabilities. We, therefore, proposed a system design that employs the concept of spimes, which we hold as being capable of partially defetishizing commodities by providing the necessary data about relationships during production in order to provide a firm basis for looking at the whole life cycle of the product. This design also provides the means to rank products according to different values, in order to assist citizen-consumers in choosing the best available products. Finally, when there are no products meeting the requirements of citizenconsumers, the design provides the capability to use a conditional purchase order to specify a price and characteristics of a product that would be satisfactory. This information could help to communicate demand to producers who may then choose to shift production methods in order to meet the new demand.

Together, these innovations could provide a robust means of educating and empowering citizen-consumers to participate in strong forms of food democracy. Otherwise, we would risk only assuaging affluent consumer guilt. However, there are difficulties as well. The development and maintenance of content in the online system will likely be a challenge that will require careful consideration. Because the model is computer-based it is more easily adopted by the affluent.

This work contributes to the discourse about food ethics by providing new ways to consider ethical principles and values and the way that they may be enacted through spimes that have the potential to partially defetishize commodities.

Acknowledgements Daryl Hepting acknowledges the support of the Natural Sciences and Engineering Research Council of Canada. The authors also wish to thank Jaz Choi and Marcus Foth for their encouragement.

\section{References}

Alders RG, Pym RAE (2009) Village poultry: still important to millions, eight thousand years after domestication. World's Poultry Science Journal 65:181-190

Barratt M (2004) Understanding the meaning of collaboration in the supply chain. Supply Chain Management: An International Journal 9(1):30-42

Benckler Y, Nissenbaum H (2006) Commons-based Peer Production and Virtue. The Journal of Political Philosophy 14(4):394-419

Brom FWA (2000) Food, consumer concerns, and trust: Food ethics for a globalizing market. Journal of Agricultural and Environmental Ethics 12:127-139

Carrington MJ, Neville BA, Whitwell GJ (2010) Why ethical consumers don't walk their talk: Towards a framework for understanding the gap between the ethical purchase intentions and actual buying behaviour of ethically minded consumers. Journal of Business Ethics 97:139-158

Cash D, Clark W, Alcock F, Dickson N, Eckley N, Jäger J (2002) Salience, credibility, legitimacy and boundaries: Linking research, assessment and decision making. Tech. Rep. RWP02-046, John F. Kennedy School of Government Harvard University Faculty Research Working Papers Series

Corsten D, Kumar N (2005) Do suppliers benefit from collaborative relationships with large retailers? an empirical investigation of efficient consumer response adoption. Journal of Marketing 69(3):80-94

Evans D (2011) Consuming conventions: sustainable consumption, ecological citizenship and the worlds of worth. Journal of Rural Studies 27(2):109-115

Follett JR (2009) Choosing a food future: Differentiating among alternative food options. Journal of Agricultural and Environmental Ethics 22:31-51 
Hassanein N (2003) Practicing food democracy: a pragmatic politics of transformation. Journal of Rural Studies 19(1):77-86

Hepting D, Maciag T, Rizvi S (2007) Information technology in support of sustainable food choices. In: Proc. International Symposium on Environmental Software Systems

Horne M, Shirley T (2009) Co-production in public services: A new partnership with citizens (discussion paper). Tech. rep., U.K.: Cabinet Office [The Strategic Unit]

Hudson I, Hudson M (2003) Removing the veil? commodity fetishism, fair trade, and the environment. Organization \& Environment 16(4):413-430

J J BloomBecker O 16-17(4-1) (1987) Computer ethics: an antidote to despair. SIGCAS Computers and Society 16(4):3-11

Jaffe J (2008) Understanding food knowledge and domestic skills: Three generations in the family kitchen, paper presented at the Annual Meetings of the Agriculture, Food and Human Values Society, New Orleans, LA. June 4-7, 2008

Jaffe J (2009) Choosing quality: the knowledge intensification shift. In: Walters L, Phoenix LE (eds) Critical Food Issues: Problems and State-of-the-Art Solutions Worldwide, vol 2, Praeger, Westport, CT, pp 101-117

Jaffe J, Gertler M (2006) Victual vicissitudes: Consumer deskilling and the (gendered) transformation of food systems. Agriculture and Human Values 23(2):143-162

Johnston J, Biro A, MacKendrick N (2009) Lost in the supermarket: The corporate-organic foodscape and the struggle for food democracy. Antipode 41(3):509-532

Kelsey J, Schneier B (1997) Conditional purchase orders. In: Proceedings of the 4th ACM Conference on Computer and Communications Security, pp 117-124

Korthals M (2006) The ethics of food production and consumption. In: Frewer L, van Trijp $\mathrm{H}$ (eds) Understanding Consumers of Food Products, Woodhead, Cambridge (UK), pp 624-642

Levkoe CZ (2011) Towards a transformative food politics. Local Environment 16(7):687-705

Linders D (2012) From e-government to we-government: Defining a typology for citizen coproduction in the age of social media. Government Information Quarterly 29(4):446-454

Lusk JL, Briggeman BC (2009) Food values. Amer J Agr Econ 91(1):184-196

Maciag T, Hepting DH (2010) Constructing collaborative online communities for visualizing spimes. In: Web Intelligence/IAT Workshops, pp 436-439

Marsh K (2011) The illusion of transparency. Political Quarterly 82(4):531-535

Marx K (1992/1867) Capital: A Critique of Political Economy, vol 1. Penguin, London

McDonough W, Braungart M (2002) Design for the triple top line: new tools for sustainable commerce. Corporate Environmental Strategy 9(3):251-258

Mechlem K (2004) Food security and the right to food in the discourse of the united nations. European Law Journal 10(5):631-648

Mepham B (2000) A framework for the ethical analysis of novel foods: The ethical matrix. Journal of Agricultural and Environmental Ethics 12:165-176

Munda G (2004) Social multi-criteria evaluation: Methodological foundations and operational consequences. European Journal of Operational Research 158(3):662-677

Nilsson H, Tunçer BA, Thidell $\AA$ (2004) The use of eco-labeling like initiatives on food products to promote quality assurance-is there enough credibility? Journal of Cleaner Production $12(517-526)$

Pariser E (2011) The Filter Bubble: What the Internet is Hiding from You. Penguin

Regattieri A, Gamberi M, Manzini R (2007) Traceability of food products: General framework and experimental evidence. Journal of Food Engineering 81(2):347-356

Singer P, Mason J (2006) The Way We Eat: Why Our Food Choices Matter. Holtzbrinck

Sparks NHC (2006) The hen's egg - is its role in human nutrition changing? World's Poultry Science Journal 62:308-315

Sterling B (2005) Shaping Things. MIT Press

Surai PF, Sparks NHC (2001) Designer eggs: from improvement of egg composition to functional food. Trends in Food Science \& Technology 12:7-16

Turilli M, Floridi L (2009) The ethics of information transparency. Ethics and Information Technology 11(2):105-112

Vermeir I, Verbeke W (2006) Sustainable food consumption: exploring the consumer "attitudebehavioral intention" gap. Journal of Agricultural and Environmental Ethics 19(2):169-194

Webster AJF (2001) Farm animal welfare: the five freedoms and the free market. The Veterinary Journal 161:229-237 
Whitmore A, Anderson DF, Zhang J, Luna-Reyes LF (2010) A policy framework for evaluating full information product pricing (FIPP) regimes. In: Proceedings of the 11th Annual International Digital Government Research Conference on Public Administration Online: Challenges and Opportunities, pp 233-234

Wilkins JL (2005) Eating Right Here: Moving from Consumer to Food Citizen. Agriculture and Human Values 22(3):269-273

Winter M (2003) Embeddedness, the new food economy and defensive localism. Journal of Rural Studies 19(1):23-32

Worosz M, Knight A, Harris C, Conner D (2008) Barriers to entry into the specialty red meat sector: The role of food safety regulation. Southern Rural Sociology 23(1):170-207

Young W, McDonald KHS, Oates CJ (2010) Sustainable consumption: Green consumer behaviour when purchasing products. Sustainable Development 18:20-31

Zwart H (2000) A short history of food ethics. Journal of Agricultural and Environmental Ethics 12:113-126 